Two Nordic existential comedies: Smiles of a Summer Night and The Kingdom

Grodal, Torben Kragh

Published in:

Journal of Scandinavian Cinema

DOI:

10.1386/jsca.4.3.231_1

Publication date:

2014

Citation for published version (APA):

Grodal, T. K. (2014). Two Nordic existential comedies: Smiles of a Summer Night and The Kingdom. Journal of Scandinavian Cinema, 4(3), 231-238. https://doi.org/10.1386/jsca.4.3.231_1 


\section{Two Nordic existential comedies: Smiles of a Summer Night and The Kingdom}

\section{ABSTRACT}

1.
The article analyses Ingmar Bergman's Smiles of a Summer Night and Lars von Trier's The Kingdom. By means of evolution and-neurology-based humour theory it shows how the two directors who ordinarily make dark and tragic films - use humour mechanisms from mainstream entertainment to transform tragic and painful situations into a social ritual of mirth.

Ingmar Bergman and Lars von Trier are two outstanding Nordic direc- tors best known for tragic films that evoke existential angst and melancholy. The driving force of the deep pain in their tragic films is linked to concerns about human nature, especially the inability to establish bonds to other people and the prevalence of selfish desires (see Grodal 2009, 2012 on von Trier). Both filmmakers, however, have made comedies that play through some of the same interpersonal problems but use comic frames to derive pleasure from the pain. In this article I will use Bergman's Sommarnattens leendel Smiles of a Summer Night (1955) and

\section{KEYWORDS}

Lars von Trier Ingmar Bergman comedy theory social ritual film aesthetics Smiles of a Summer Night

The Kingdom 
Trier's TV series Riget/The Kingdom $(1994,1997)$ to show how this comic reframing of existential pain takes place.

To clarify the mechanisms of such a reframing, let me first sketch some fundamental mechanisms in comic entertainment based on what I propose as a new theory of the comic, synthesizing the most important previous theories within a neurological framework (Grodal 2014). The synthesis aims to resolve a series of problems that arise if the focus is solely on one aspect of the complex reaction mechanisms (on humour see also Martin 2007).

Comic entertainment is a sophisticated development of mammalian play mechanisms. The most primitive forms consist of performing actions that might normally evoke negative emotions and lead to problematic consequences, such as fighting and pursuit, but also to exploration and growth. Due to deep-seated mental mechanisms, young animals and children may play through situations of aggression and fear without hurting each other, instead gaining pleasure from the activities.

To give an example: in Smiles of a Summer Night a central narrative transition that convinces the puritan young clergyman Henrik to abandon Christian chastity is signalled when the coachman Frid play-chases Petra, the maid, and she screams with playful sexual excitement while pretending to elude him. Her screaming is also a play signal, and thus the arousal caused by being chased is transformed to signals of sexual abandonment. If a situation, say a fight or flight, is signalled as playful, the participants are on the one hand aroused, activating stress hormones like adrenaline and cortisol, but at the same time quantities of pleasure-and-relaxation neurotransmitters of the opioid group, such as endorphins, are released. Comedies are sophisticated ways of working through arousing but often quite painful events. The wide range of subgenres includes horror comedies, action comedies, romantic comedies and not least, comedies that play through scenes of shame, failure, loss and embarrassment in social interaction.

In erotic encounters, the play situation serves to dismantle the modesty-related protection of the body from intrusion by others. By using play-chasing, Bergman highlights in a joyful manner the conflict between, on the one hand, the need for body autonomy and the fear of losing control and, on the other hand, the playful pleasures of abandoning that autonomy in tender and erotic bodily fusion. This contrasts with Bergman's tragic films where the body is a seat of pain.

Central to comic situations is thus not only to produce such arousal that would normally motivate muscular actions that could alleviate the cause of arousal (escaping, killing an opponent, satisfying sex drives, crying out of sadness, evading loss of body autonomy) but also to define the situation as 'unreal' or 'playful', making any such action unnecessary. The audience can just enjoy the arousal, even if it is caused by pain or shame. In contrast to the dominant conceptions of the comic, such as incongruence theories (see Martin 2007), in which some behaviours or mental states are in their essence funny, the general theory claims that the 'fuel' of the comic is ordinary arousal and the comic result is caused by situation-specific signalling and negotiation of a play situation that makes the arousal 'unreal', backed up by innate physiological reactions, including the release of endorphins (pleasure-evoking neurotransmitters). It is important to emphasize that the comic evaluation of something as 'unreal' or 'playful' can be
1.

2.

3.

4.

5.

6.

7.

8.

9.

10.

11.

12.

13.

14.

15.

16.

17.

18.

19.

20.

21.

22.

23.

24.

25.

26.

27.

28.

29.

30.

31.

32.

33.

34.

35.

36.

37.

38.

39.

40.

41.

42.

43.

44.

45.

46.

47.

48.

49.

50.

51.

52. 
1. seen as a bail-out mechanism from negative experiences, because often their causes are very real, and only the shared decision to laugh at them makes it possible to enjoy the painful arousal.

The signalling and negotiation of the play situation rely on basic mechanism of bonding, and thus comedy is a profoundly social institution by means of which groups may gain comfort by playful sharing of their negative experiences (but also by exclusion so that the group laughs at other persons and groups). A difficult question, however, remains how to signal and negotiate that a given event should be experienced as playful, pleasurable and 'unreal'. Animals and children may emit play signals such as specific sounds or laughter to convey that 'this fight is for fun', and audiences of comic entertainment likewise express themselves by laughing, thus also signalling to other members of the audience that the event is experienced as comic, playful and shared by the group.

Film characters, however, cannot usually signal the playfulness of the comedy by laughing all the time. Instead they need to signal arousal, for instance surprise, pain or shame. A person who laughingly slips on a banana peel is not as funny as the person who shows surprise, shame or pain by falling. Comic entertainment therefore develops other ways to signal playfulness, which I will exemplify in relation to works of Bergman and Trier. Some of these signals are conventions - even highly original film-makers such as Bergman and Trier need conventional play signals in order to transform pain, shame and other negative causes of arousal to comic pleasure. The use of conventions is therefore necessary to establish the play contract. Although high art critics and even the film-makers themselves may regard such a mix of conventions and originality as less elevated than pure avant-garde art, comedy activates the very roots of art: to create a social ritual to regulate the emotional impact of central human experiences.

\section{COMIC CONVENTIONS MEET MORAL ANXIETY}

Smiles of a Summer Night was forced on Bergman in the sense that he was under economic pressure to make a film that could succeed at the box office. Perhaps in part for that reason, he borrows proven formulas from several centuries of French theatrical tradition, including the comedies of Pierre de Marivaux and Pierre Beaumarchais and plays from the so-called belle époque, for instance those of Georges Feydeau; French film comedies such as Max Ophuls' La Ronde/The Round (1950) also served as models. Central in such comedies is the use of promiscuous sex and moral transgressions such as infidelity to create arousal. Bergman even follows a centuries-old French tradition by portraying the servant class and the aristocracy as more promiscuous than the middle classes: the maid Petra signals her willingness to the men around her, and Count Malcolm is on principle a Don Juan with no intention of being faithful to his wife. Part of the arousal is thus caused by portraying relatively uncontrolled sexual behaviours and by a series of embarrassing confrontations caused by the philandering.

However, the arousal is partly transformed, becoming humorous and unrealistic, by the use of character stereotypes and conventional plot devices. These stereotypes are clear play signals telling the audience of the mid-1950s that the callousness is part of a social ritual that may be enjoyed without the customary moral restrictions on enjoying promiscuity. The historical setting reinforces this play signal. The film further 
incorporates a series of classic slapstick devices. An example: one of the main characters, Fredrik Egerman, is humiliated by falling into a puddle so his clothes become wet, causing him to borrow a comical night outfit, including a ridiculous cap. In this attire he is caught unawares by its rightful owner, the jealous Count Malcolm. Much later, a duel between the two competitors for the favour of actress Desirée Armfeldt takes the form of Russian roulette - except that the gun is loaded with soot. Fredrik does not die, but is once again humiliated in a comical manner when soot covers his face.

Although stereotyping and slapstick send a steady stream of play signals, beneath the surface lurks pain caused by fear of separation from loved ones and conflict between family members, the type of conflict that is central to other Bergman films. This might be described as the tradition of the tragic Nordic fin de siècle as expressed in the dramas of Ibsen and Strindberg. Bergman's oeuvre mostly focuses on a sense of abandonment and the failure to bond, whether in a cosmic-existential context as portrayed in Det sjunde inseglet/The Seventh Seal (Bergman, 1957) or in interpersonal relationships, as in, among others, Smultronstället/Wild Strawberries (Bergman, 1957), Såsom $i$ en spegell Through a Glass Darkly (Bergman, 1961) and Persona (Bergman, 1966).

In Smiles of a Summer Night a prominent reason for separation panic is jealousy, the feeling of being betrayed experienced by several of the characters. Moral conflict is another cause of arousal, as seen in the young clergyman Henrik, who feels torn between his ideal of Christian virtue and his sexual urges. (These urges have a slightly Oedipal twist by being partly directed at his father's young wife Anne.) The moral conflict does not, however, lead to a tragic outcome. Instead, when Henrik tries to commit suicide he accidentally activates a 1 . button that brings Anne, asleep in 2 . her bed, into his room. Shortly there- 3 . after the two elope. Love conquers 4 . conventional morality. The romantic 5 . elopement, calling to mind that tradi- 6 . tional comedy generally concludes 7 . with a marriage, is in turn juxtaposed 8 . with the sexual encounter between 9 . Petra and Frid, a joyful frolic unlikely 10. to lead to permanent commitment. 11.

In addition to the classic ritual- 12. ized play signals of comedy, Smiles of 13. a Summer Night incorporates lyrical- 14. mythic play signals centred around 15. the mystique of the summer night 16 . that has provided the film with its 17. title. The coachman Frid claims that 18. the midsummer night has three 19. smiles, the first for those who open 20. their hearts and their bodies, the 21. second for the fools, and the third for 22. those in emotional pain. These three 23. smiles serve as background to the 24 . erotic encounter between Petra and 25. Frid, and seem to point to a pantheis- 26. tic, 'heathen' romantic fatalism where 27. Mother Nature laughingly embraces 28. all human beings and 'comically' 29. diminishes their pain. This romantic 30. fatalism is supported by the images 31 . of nature that supplement the theat- 32 . rical flavour of indoor scenes; the 33 . bucolic outdoor scenes seem to draw 34 . on Swedish folklore and indicate an 35. alternative to Nordic Protestantism. 36. Lyrical sex in a nature setting had 37. been present in Arne Mattsson's 38. Golden Bear-winning Hon dansade 39. en sommar/One Summer of Happiness 40. (1951) and Bergman's Sommaren med 41. Monika/Summer with Monica (1953), 42. just as one of the first Nordic exam- 43. ples of female nudity (in nature) 44 . was Bjarne Henning Jensen Ditte 45. Menneskebarn from 1946. Such films 46. established the mid-century interna- 47. tional perception of the Scandinavian 48 . countries as having a'natural', eman- 49. cipated relation to sex. For Bergman, 50. the comic form allowed him to 51 . express moral double standards, to 52. 
1. embrace both carnal delight and 2. romantic love.

3.

4.

5.

6.

\section{MEDIA COMEDY MEETS EXISTENTIAL ANXIETY}

Some of Trier's basic tragic problems are similar to those of Bergman: the frailty of human bonding, especially the absence of motherly love, and unfaithfulness; additionally Trier's take on the problems of care and bonding may - as in The Kingdom - focus on abuse. During his work on The Kingdom he also made Breaking the Waves (1996), which highlights the sexual abuse a crippled husband demands that his wife undergo to feed his sexual imagination. Trier's previous work for television, Medea (1988), concerns a woman who kills her own sons by hanging and poisons her husband's new wife. The themes of problematic care and bonding are intimately linked to anxiety about the frailty of the human body as a physical object and the conflict between modesty and lust (cf. Grodal forthcoming). However, The Kingdom is unusual in Trier's oeuvre for linking the problem of care in close personal relations to that of 'social care' as exemplified in the hospital (and linked, in turn, to his personal ambivalence about bonding-related emotions, caused by his psychological anxieties (Björkman 2003)).

Trier plays with the possibility of escaping from what he sees as scientific materialism violating the sanctity of the body. He comes to a world of spiritualism, but since Trier is a little shy of committing himself to this perspective, he frames it as partly comic. Furthermore, as often in the case of supernaturalism, when the agents of good acquire magic powers so do the agents of evil. Therefore the world becomes chaotic due to a lack of stable causal forces.

The centre of the abusive materialism is the hospital, a perfect setting for portraying the frailty of body and mind, here made more terrifying by transforming the doctors from healers to abusers of patients (or of themselves, as in the case of a doctor transplanting a diseased organ into his own body). In contrast to Trier's previous films, where abuse takes place in the past, The Kingdom converts a central symbol of care of body and mind into a symbol of abuse taking place in the heart of contemporary Denmark.

An arousal that feeds on fear, disgust and shame needs strong play signals to be transformed into comic pleasure for a mainstream audience. Trier's take on comedy has a quite different background than the classical theatrical devices in Smiles of a Summer Night, partly because the nearly 40 years between that film and The Kingdom have replaced theatre with a world of media. Trier uses the genres of mainstream film and television to produce arousal and to provide stereotypes and exaggerations that may be used to signal comic playfulness. The generic roots of The Kingdom are horror fiction, especially David Lynch's Twin Peaks (19901991) and Claude Barmas' Belphegor (1965) (see Schepelern 2000), and hospital soaps and sitcoms with some touches of crime fiction. In the introduction he additionally borrows lyrical elements from the art film (Tarkovsky). The TV series is thus able to draw on a wide range of emotions to create arousal, for instance horror, fear, curiosity, sexual desire, and very often disgust provoked by violation of body integrity. The play signalling is often achieved by creating a conflict between different generic features or by presenting them in an exaggerated fashion, for instance by letting hyperbolic horror elements exist side by side with sitcom elements.

Also central for arousal in The Kingdom are emotions cued by interpersonal relations where people 


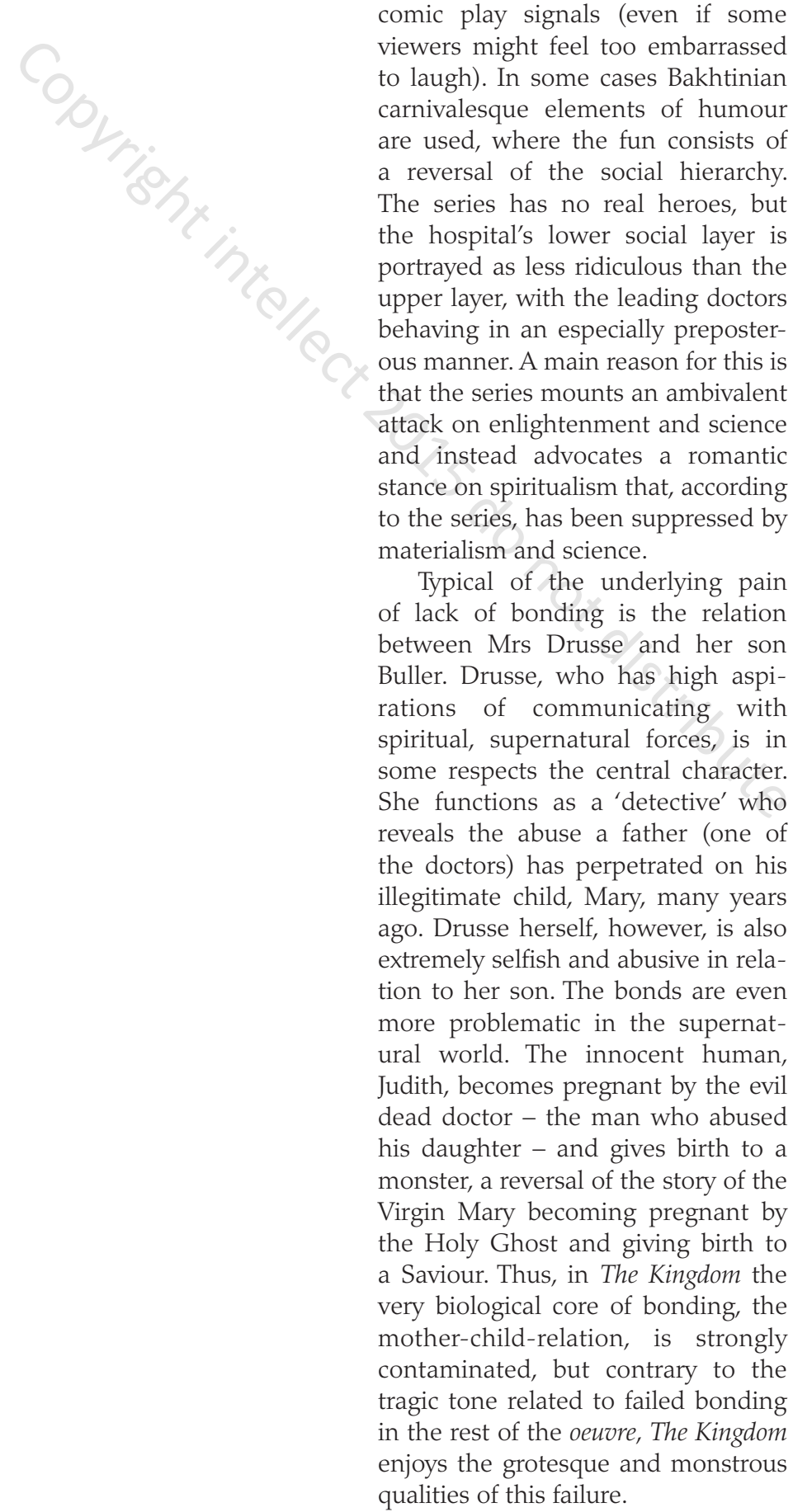

humiliate each other, cheat, or behave in a ridiculous or embarrassing fashion, as is typical in sitcoms. These emotional situations often serve as comic play signals (even if some viewers might feel too embarrassed to laugh). In some cases Bakhtinian carnivalesque elements of humour are used, where the fun consists of The series has no real heroes, but the hospital's lower social layer is portrayed as less ridiculous than the upper layer, with the leading doctors behaving in an especially preposterous manner. A main reason for this is bivalent and instead advocates a romantic stance on spiritualism that, according to the series, has been suppressed by aterialism and science.

Typical of the underlying pain between Mrs Drusse and her son Buller. Drusse, who has high aspirations of communicating with spiritual, supernatural forces, is in She functions the central character. reveals the abuse a father (one of the doctors) has perpetrated on his illegitimate child, Mary, many years ago. Drusse herself, however, is also extremely selfish and abusive in relaare even ural world. The innocent human, Judith, becomes pregnant by the evil dead doctor - the man who abused his daughter - and gives birth to a monster, a reversal of the story of the by the Holy Ghost and giving birth to very biological core of bonding the mother-child-relation, is strongly contaminated, but contrary to the in the rest of the oevore, The Kingdo qualities of this failure.
Compared with Smiles of a 1 . Summer Night, The Kingdom is dark 2. and grim. In Bergman, the comic 3. form is used to soften the existen- 4 . tial angst and the moral problems 5 . created by carnal desire. Bergman's 6 . comedy ends on a cautiously opti- 7 . mistic note: the young lovers are 8 . united and the middle-aged couple, 9. Fredrik and Desiree reunite to share 10. the parenting of their child. In 11. contrast, in Trier's serial the comic 12. sugar-coating is used to let people 13 . enjoy an extremely dark vision of 14 . the world ruled by immoral forces, 15. where bodies are sick, violated or 16 . contaminated and minds are totally 17. self-involved. Furthermore, social 18. institutions are portrayed as deeply 19. corrupt and incompetent. 20.

\section{CONCLUSION}

In the grand picture of cultural history, Bergman unites an eighteenth-century spirit of licentiousness with small touches of nineteenthcentury Protestant pain. In contrast, Trier's tack is to merge dark romanticism à la Mary Shelley's novel Frankenstein from 1818 with twentieth-century social angst as portrayed in zombie films, but also in the social embarrassment and shame that feed sitcoms where arousal is sugar-coated with comic unrealness. The comedy serial is also, of course, a love and hate tribute to the mainstream film and TV genres that Trier parodies.

Bergman created Smiles of a Summer Night in part by using play signals borrowed from the world of French theatre, whereas Trier shaped The Kingdom with play signals from a world of American film and TV as well as elements from art film and Danish folk comedy. In accordance with my general theory of comic entertainment, the main sources of pleasure are arousal due to negative emotions (even if some of the 
pleasures of Smiles of a Summer Night derives from sexual licentiousness) that are transformed to pleasure via play signals and shared play conventions among the spectators. Such conventions are not held in high regard in the art film community; pain and melancholy in tragic films confer more prestige than comic joy, even among film-makers. Thus Trier regarded The Kingdom as a 'left hand work', that is, not central to his oeuvre. However, a main function of comedy may be considered a kind of mental therapy that allows people to deal with negative emotions that become more accessible in a frame of comic unrealness. For Bergman personally, making Smiles of a Summer Night was therapeutic in one of the darkest periods of his life (see Björkman et al. 1993) and resulted in his international breakthrough: the film won a prize in Cannes. Similarly, in The Kingdom Trier deals with some of his most personal anxieties linked to family and illness (see Björkman 2003), but in a form that made the series his breakthrough into public recognition. By incorporating the conventions of various popular genres in the form and content of their comedies, the directors may even be performing a kind of personal therapy, letting fears and desires surface within the framework of comic playfulness and unrealness. From a neurological point of view, comic and tragic reactions are closely related: crying and laughing share most of their neurological support. Both reactions are based on self-modification in response to emotional overload and both reactions invite other people to share them. There is therefore some logic in the fact that these two Nordic film-makers of tragedies tried the other solution to negative emotional overload: to laugh, and invite their audiences to participate in a shared therapy.

\section{REFERENCES}

Björkman, Stig (2003), Trier on von Trier, London: Faber and Faber.

Björkman, Stig, Manns, Torsten, Sima, Jonas and Britten Austin, Paul (1993), Bergman on Bergman: Interviews with Ingmar Bergman, Cambridge, MA: Dacapo Press.

Grodal, Torben (2009), Embodied Visions. Evolution, Emotion, Culture and Film, New York: Oxford University Press.

(2012), 'Frozen style and strong emotions of panic and separation - Trier's prologues to Antichrist and Melancholia', Journal of Scandinavian Cinema, 2: 1, pp. 47-53.

(2014), 'A general theory of comic entertainment: Arousal, appraisal and the PECMA

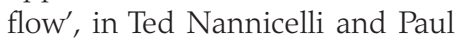
Taberham (eds), Cognitive Media Theory, London: Routledge/AFI Film Readers, pp. 177-95.

(forthcoming 2015), 'Antichrist, explicit sex, anxiety, and care', in Lindsay Coleman (ed.), Sex and Storytelling in Modern Cinema: Explicit Sex, Performance and Cinematic Technique, London: I. B. Tauris.

Martin, Rod A. (2007), The Psychology of Humor. An Integrative Approach, London: Elsevier.

Schepelern, Peter (2000), Lars von Triers Film: Toang og Befrielse. København: Rosinante.

\section{FILM AND TELEVISION REFERENCES}

Belphegor (1965, France).

Bergman, Ingmar (1953), Sommaren med Monika, Sweden.

- (1955), Sommarnattens leende, Sweden.

(1957), Det sjunde inseglet, Sweden. (1957), Smultronstället, Sweden. (1961), Såsom $i$ en spegel, Sweden. 
(1966), Persona, Sweden.

Jensen, Bjarne Henning (1946), Ditte Menneskebarn, Denmark.

Lynch, David (1990-91), Twin Peaks, USA.

Mattsson, Arne (1951), Hon dansade en sommar, Sweden.

Ophuls, Max (1950), La Ronde, France.

Trier, Lars von (1988), Medea, Denmark.

Riget I-II (1994, 1997): Denmark. (1996), Breaking the Waves, Denmark.

\section{SUGGESTED CITATION}

Grodal, T. (2014), 'Two Nordic existential comedies: Smiles of a Summer Night and The Kingdom', Journal of Scandinavian Cinema 4: 3, pp. 231-238, doi: 10.1386/ jsca.4.3.231_1

\section{CONTRIBUTOR DETAILS}

Torben Grodal is professor emeritus in film at the University of Copenhagen. In addition to books and articles on literature he has authored Moving Pictures (1997), Embodied Visions: Evolution, Emotion, Culture and Film (2009), an introduction to film theory in Danish, Filmoplevelse (2 ed., 2007) and published a series of articles on film, emotions, narrative theory, art films, video games and evolutionary film theory.

Contact: grodal@hum.ku.dk

Torben Grodal has asserted their right under the Copyright, Designs and Patents Act, 1988, to be identified as the author of this work in the format that was submitted to Intellect Ltd.
1.

2.

3.

4.

5.

6.

7.

8.

9.

10.

11.

12.

13.

14.

15.

16.

17.

18.

19.

20.

21.

22.

23.

24.

25.

26.

27.

28.

29.

30.

31.

32.

33.

34.

35.

36.

37.

38.

39.

40.

41.

42.

43.

44.

45.

46.

47.

48.

49.

50.

51.

52. 